\title{
ANNEALING OF UNFERMENTED (POLVILHO DOCE) AND FERMENTED (POLVILHO AZEDO) CASSAVA STARCHES
}

\author{
ANIDA MARIA MORAES GOMES* \\ CLÁUDIO ERNANI MENDES DA SILVA** \\ PALOMA LIMA DA SILVA ${ }^{* \star *}$ \\ NÁGILA MARIA PONTES SILVA RICARDO**** \\ MARIA ISABEL GALLÃO*****
}

\begin{abstract}
The effects of annealing on the properties of unfermented (polvilho doce-PD) and fermented (polvilho azedo-PAD) cassava starches were studied. The samples were submitted to annealing treatment for 24, 72, 96, 144, 192 and 240 hours. The annealing treatment changed the main physicochemical (gelatinization, enthalpy and temperature) and rheological properties (swelling power, peak viscosity and pasting temperature) of the both samples. The increase in the gelatinization temperatures and the narrowing of the gelatinization range was attributed to an reinforcement in the packing of the double helices of the amylopectin. The PAD samples seemed to be more affected by this treatment than PD ones. The PAD samples presented some characteristics of a waxy starch, such as increased crystallinity and increased stability of the pastes, which from a technological point of view is very important to diversify further its use in the food industry.
\end{abstract}

KEY-WORDS: CASSAVA STARCH; "POLVILHO DOCE"; "POLVILHO AZEDO"; ANNEALING.

* Doutora em Química Inorgânica, Laboratório de Polímeros, Departamento de Química Orgânica e Inorgânica, Universidade Federal do Ceará (UFC), Fortaleza, Ceará (e-mail: anidamoraes@yahoo.com.br).

** Doutor em Tecnologia de Alimentos, Professor Adjunto, Laboratório de Cereais, Departamento de Tecnologia de Alimentos, UFC, Fortaleza, Ceará (e-mail: cernani@ufc.br).

*** Mestre em Química Inorgânica, Laboratório de Polímeros, Departamento de Química Orgânica e Inorgânica, UFC, Fortaleza, Ceará (e-mail: paloma_pls@yahoo.com.br).

**** Pós-doutorado em Química de Polímeros, Professora Adjunto, Laboratório de Polímeros, Departamento de Química Orgânica e Inorgânica, UFC, Fortaleza, Ceará (e-mail: naricard@ufc.br).

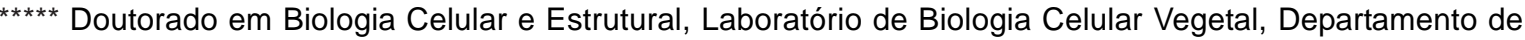
Biologia, UFC, Fortaleza, Ceará (e-mail: edybel@ufc.br). 


\section{INTRODUCTION}

The cassava (Manihot esculenta Crantz) belongs to the Euphorbiaceae family and is the main source of carbohydrates on the food of some developing countries. Depending on the manufacturing process of cassava starch, it can be named as "polvilho doce" (unfermented) or "polvilho azedo" (fermented). The first is obtained after the grating of the fresh roots, sedimentation and drying at sun. On the latter, the roots are grated and the pulp left to ferment naturally for 30 to 40 days (CEREDA, 1987).

The starches can have their physicochemical properties modified by several physical and chemical treatments. Physical treatments as annealing and heat-moisture (HMT), just use heat and water, but they modify significantly the properties of the starches (LIM, CHANG and CHUNG, 2001; VERMEYLEN, GODERIS and DELCOUR, 2006). The first observations of the effects of annealing on starch were probably reported by Gough and Pybus (1971). Annealing is generally carried out by heating granular starch with a large quantity of water, at temperature below the starch melting point, whereas HMT is carried out at limited moisture contents but at an elevated temperature (ELIASSON and GUDMUNDSSON, 1996). In this process the arrangement of the macromolecules undergoes subtle changes resulting from rearrangement of hydrogen bonds which are broken during the gelatinization process and reformed as the granule components attain a state of more ordered crystal conformation.

The annealing modifies the physicochemical properties of starch without destroying its granular structure (LARSSON and ELIASSON, 1991; JACOBS and DELCOUR, 1998). These modifications however, depend on temperatures, time of treatment, starch to water ratio, botanical species and manufacturing process of starch. The annealing process decrease the swelling power and solubility of starches (EERLINGER, JACOBS and BLOCK, 1997), increase the gelatinization temperatures and enthalpy of treated starches (STUTE, 1992; TESTER and DEBON, 2000), increase the susceptibility to amilases (WANG, POWEL \& OATES, 1997) and change the curves of development of pasta (STUTE, 1992).

Jacobs et al. (1995) reported an increased gelatinization temperature and enthalpy, a narrower gelatinization temperature range, and an increase in peak viscosity and viscosity upon cooling for pea, wheat and rice annealed for 24 hours. Annealing of potato starch does not (KARLSSON and ELIASSON, 2003) or only moderately (NAKAZAWA and WANG, 2003; TESTER et al., 2005) increase enthalpy of gelatinization. Starch annealing has been sugested to induce crystal growth or perfection, although it does not increase crystallinity (TESTER et al., 2005).

The aim of this study was to compare the effects of annealing treatment on the properties of polvilho azedo and polvilho doce.

\section{EXPERIMENTAL}

\subsection{ANNEALING PROCEDURE}

The annealing treatment of the commercial samples of polvilho doce (PD) and polvilho azedo (PAD) were obtained after steeping in water (1:5 starch/water) to $50^{\circ} \mathrm{C}$ for $24,72,96,144,192$ and 240 hours, according to Gough and Pybus (1971).

\subsection{SWELLING POWER AND SOLUBILITY}

The swelling power and solubility analysis were determined by Schoch methodology $(\mathrm{SCHOCH}, 1964)$. About $1 \mathrm{~g}$ of sample and $40 \mathrm{~mL}$ of water were submitted to heating to temperatures of $55,65,75,85$ and $95^{\circ} \mathrm{C}$. After cooling, the slurry of starch was centrifuged $5000 \mathrm{xg}$ for $30 \mathrm{~min}$. The supernatant was carefully separated from the sediment, and $10 \mathrm{~mL}$ were removed to evaluate the percentage of soluble, while the sediment was weighed for determination of the percentage of swollen granules. 
The pasting characteristics of the starches were analyzed in a rapid visco-analyzer (RVA) model RVA-4 (Newport Scientific Pty. Ltd, Australia) was used for pasting properties determinations. About 4,5g of sample were mixed with $25 \mathrm{~mL}$ of distilled water to obtain a total weight of $28 \mathrm{~g}$ in the glass of RVA. The analyses were run in triplicate. The samples were maintained for $1 \mathrm{~min}$ at $50^{\circ} \mathrm{C}$ and the temperature increased progressively up to $95^{\circ} \mathrm{C}\left(13^{\circ} \mathrm{C} / \mathrm{min}\right)$, held for $3 \mathrm{~min}$ at $95^{\circ} \mathrm{C}$ and afterwards reduced to $50^{\circ} \mathrm{C}\left(13^{\circ} \mathrm{C} / \mathrm{min}\right)$, held for $3 \mathrm{~min}$. The test was concluded after $13 \mathrm{~min}$ (NEWPORT SCIENTIFIC, 1998).

\subsection{DIFFERENTIAL SCANNING CALORIMETRY (DSC)}

Thermal characteristics of the starches were obtained by analysis in a differential scanning calorimeter Shimadzu, model DSC-50 (Shimadzu, Japan). Approximately $3 \mathrm{mg}$ of sample were placed into an aluminium sample pan, $15 \mu \mathrm{L}$ of distilled water was added to obtain a starch to water ratio of 1:3 $(w / v)$. The samples were allowed to equilibrate for $1 \mathrm{~h}$ and pans were hermetically sealed. The calorimeter was heated at $25-100^{\circ} \mathrm{C}$, under gas flow of $50 \mathrm{~mL} / \mathrm{min}$ and heating rate was to $10^{\circ} \mathrm{C} / \mathrm{min}$. The parameters of $T_{o}$ (temperature of onset gelatinization), $T_{p}$ (peak temperature), $T_{c}$ (conclusion temperature) and $\Delta \mathrm{H}$ (enthalpy of gelatinization) were obtained (SHIMADZU CORPORATION, 1989).

\subsection{X-RAYS DIFFRACTION}

The X-rays patterns of the starches were obtained in an $\mathrm{X}$-ray diffractometer Rigaku, model Dmax-B (Rigaku, Japan), with a copper radiation in line $\mathrm{K} \alpha(\lambda=0.1542 \mathrm{~nm})$, operating at $40 \mathrm{KV}$ and $25 \mathrm{~mA}$. The area of scanning of diffraction angle $(2 \theta)$ was $3-40^{\circ}\left(1 / 2^{\circ} / \mathrm{min}\right)$. The diffractograms were fitted in Origin 6.0 software (MICROCAL INC., 1996).

\subsubsection{Relative Crystallinity}

The relative crystallinity was determinate according to Herman's methods, as described in Fujita et al. (1998). A smooth curve which connected peak baselines was computer-plotted on the diffractograms obtained in $\mathrm{x}$-ray analysis (Figure 1). The area above the smooth curve was taken as the crystalline portion and the lower area between smooth curve and the linear baseline which connected the two points of the intensity $2 \theta$ of $30^{\circ}$ and $5^{\circ}$ in the samples was taken as the amorphous section. The upper diffraction peak area and the total diffraction area over the diffraction angle $5^{\circ}-30^{\circ} 2 \theta$ were integrated using Origin 6.0 software (MICROCAL INC., 1996). The ratio of upper area to total diffraction was taken as the degree of crystallinity.

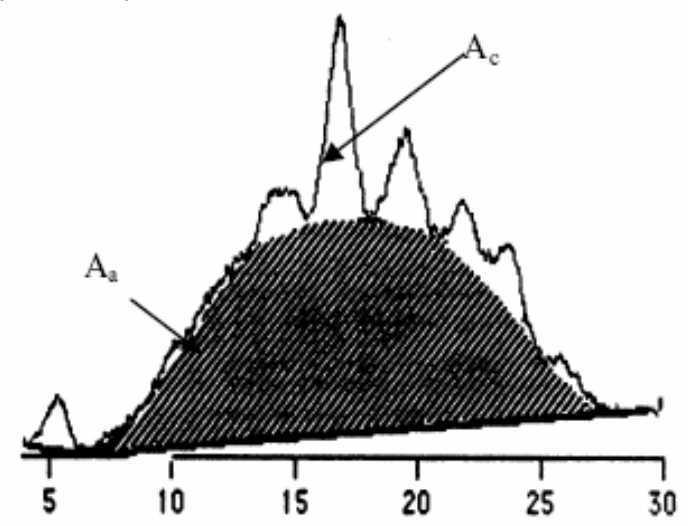

Diftraction angle (20)

FIGURE 1 - DIAGRAM FOR CALCULATION OF THE DEGREE OF RELATIVE CRYSTALLINITY 
The equation of the degree of crystallinity is as follows: $X c=A c /(A c+A a)$

Where $\mathrm{Xc}$ refers to the degree of crystallinity; Ac refers to the crystallized area on the X-ray diffractogram; Aa refers to the amorphous area on the X-ray diffractogram.

\section{RESULTS AND DISCUSSION}

\subsection{PASTING CHARACTERISTICS}

The effects of the annealing on the pasting properties of the polvilho doce (PD) and polvilho azedo (PAD) are shown in the Table 1 and Figures 2 and 3 . There was reduction in the peak viscosities of the two samples by annealing time. The samples of PD and PAD annealed by $144-240 \mathrm{~h}$ suffered the reductions more intensively. As already observed by other authors (HOOVER \& VASANTHAN, 1994; GOMES et al. 2004), the treatment reinforces the bonds between the starch molecules, making the amylose less prone to leach from the granules, which causes a decrease in the peak viscosity of the treated samples.

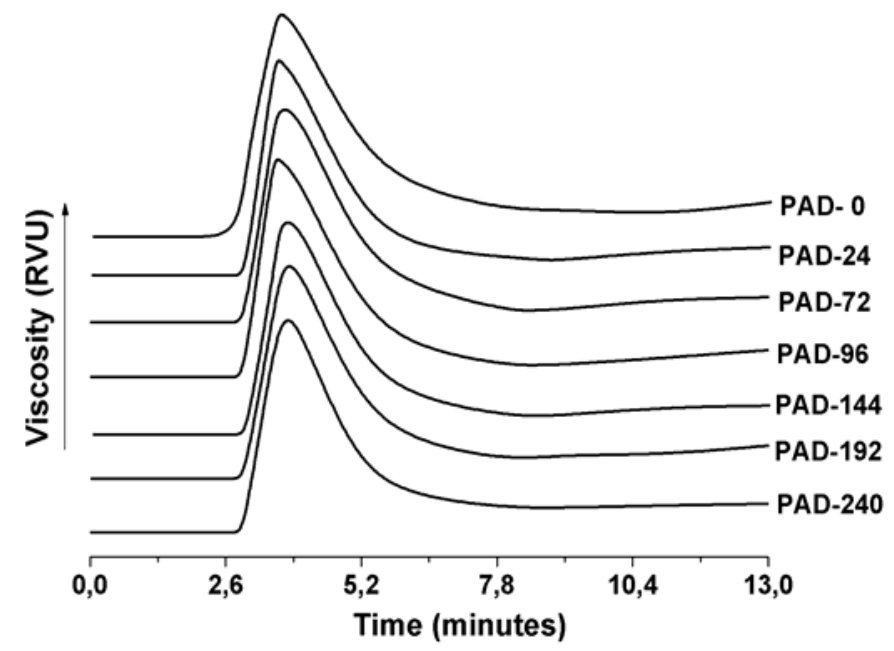

FIGURE 2 - RVA CURVES OF NATIVE AND ANNEALED PAD STARCHES

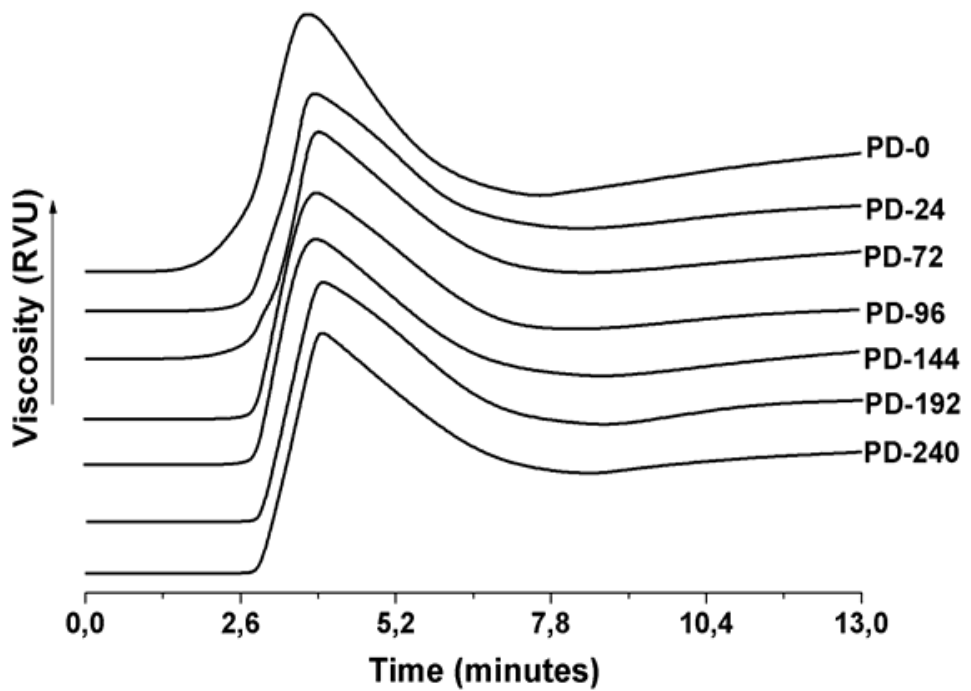

FIGURE 3 - RVA CURVES OF NATIVE AND ANNEALED PD STARCHES 
The fermentation process changed the associative forces between the molecules of PAD, which led it to a larger reorganization of its molecules in relation to PD. Thus the molecules seemed to assume a more stable conformation due to an increase in the crystalline order, which greatly influenced the pasting properties of the samples annealed. The untreated PAD presented a smaller setback than the PD. The latter however, suffered a more effective reduction in the setback $(47,0 \%)$ when the time of annealing was increased.

The cassava starch (fermented or unfermented) showed lower tendency to the retrogradation than the others starches as potato, corn, etc. The factors which probably contributed for this were the higher degree of polymerization (DP) and the lower lipids content. These can provoke a repulsive effect among the molecules, which prevented the association among them and decreased the formation of the amylose/lipids complexes.

\section{TABLE 1 - EFFECTS OF ANNEALING ON THE PASTING CHARACTERISTICS OF THE SAMPLES OF PD AND PAD ${ }^{1}$}

\begin{tabular}{|c|c|c|c|c|c|c|}
\hline$\overline{\mathrm{TIME}}$ & & $\mathrm{PD}$ & & & PAD & \\
\hline (h) & $P \vee\left(R \vee U^{2}\right)$ & $\mathrm{SB}\left(\mathrm{RV} \mathrm{U}^{2}\right)$ & $\vee\left(R \vee U^{2}\right)$ & $P \vee\left(R \vee U^{2}\right)$ & $\mathrm{SB}\left(\mathrm{RV} \mathrm{U}^{2}\right)$ & \\
\hline 0 & $5, \subseteq$ & 115,3 & $299,7 \pm 15,62^{a}$ &, $17^{a}$ & $13,6 \pm$ & $.88^{i}$ \\
\hline 24 & $643,9 \pm 1,42^{b}$ & $69,0 \pm 4,36^{b c}$ & $302,6 \pm 7,02^{a b c}$ & $266,8 \pm 0,80^{b}$ & $14,3 \pm 0,22^{b}$ & $35,5 \pm 1,26^{\mathrm{b}}$ \\
\hline 72 & $670,5 \pm 1,80^{c}$ & $62,5 \pm 1,54^{\mathrm{cd}}$ & $310,1 \pm 1,89^{\mathrm{ab}}$ & $241,8 \pm 4,00^{\mathrm{C}}$ & $14,6 \pm 0,13^{b}$ & $31,4 \pm 2,41^{b}$ \\
\hline 96 & $658,4 \pm 2,79^{\mathrm{ab}}$ & $56,7 \pm 3,22^{d}$ & $313,3 \pm 2,79^{a b}$ & $236,0 \pm 1,98^{c}$ & $15,4 \pm 0,63^{b}$ & $31,1 \pm 2,98^{b}$ \\
\hline 144 & $594,2 \pm 6,6 s$ & $63,5 \pm 3,55^{\mathrm{cd}}$ & & & $11,4 \pm 0,05^{c}$ & $22,1 \pm 0,46^{\prime}$ \\
\hline 192 & $613,1 \pm 3$ & $60,9 \pm 0$ & $307,9 \pm 0,60^{a b}$ & $183,1 \pm 2,00^{f}$ & $14,5 \pm 0,79^{a b}$ & $27,8 \pm, 87^{c}$ \\
\hline 240 & $631,9 \pm 1,48^{f}$ & $61,2 \pm 3,25^{\mathrm{cd}}$ & $314,5 \pm 4,58^{a b}$ & $177,7 \pm 0,70^{\mathrm{e}}$ & $12,4 \pm 0,30^{d}$ & $23,4 \pm 0,54$ \\
\hline
\end{tabular}

${ }^{1}$ Equal letters in the same column do not differ significantly at the $5 \%$. ${ }^{2} \mathrm{RVU}=$ Rapid Visco-analyser Unity. $\mathrm{PV}=$ peak viscosity, $\mathrm{SB}=$ setback, $\mathrm{FV}=$ final viscosity.

\subsection{SWELLING POWER AND SOLUBILITY}

The annealing restricted the swelling and the solubility of the two samples in all temperatures by the time of treatment. This can be verified in Table 2 . At $55^{\circ} \mathrm{C}$, the solubility of the samples of PD ceased after $144 \mathrm{~h}$ of treatment, while in the PAD annealed for $240 \mathrm{~h}$, the solubility was reduced by $94,1 \%$. The solubility at $95^{\circ} \mathrm{C}$ of the PD and PAD were reduced to $30,6 \%$ and $12,3 \%$, respectively, in relation to the control sample.

The swelling of the samples annealed by $240 \mathrm{~h}$ at $55^{\circ} \mathrm{C}$ were restricted in $15,4 \%$ (PAD) and $47,8 \%(P D)$, in relation to control samples. While at $95^{\circ} \mathrm{C}$ the reductions were of $43,1 \%$ and $38,5 \%$, respectively. The two fractions of amylose present in the granule, lipid-amylose complex (LAM) and free lipids amylose (FAM), interfere directly in the swelling and solubility of the starches.

FAM, which prevails in the cereals and tubers starches, interferes in the formation of the amylopectin crystals and consequently facilitates the swelling of the amorphous areas, causing their destabilization. The annealing treatment corrects this destabilization, by inducing interactions of FAM with the amylopectin molecule (forming a more stable structure), increasing the perfection of the crystals, hindering the hydration of the amorphous areas, reducing thus the solubility and the swelling as annealing time is increased. 
TABLE 2 - EFFECTS OF ANNEALING ON THE SWELLING POWER AND SOLUBILITY OF PD AND PAD AT $55^{\circ} \mathrm{C}$ AND $95^{\circ} \mathrm{C}^{1}$

\begin{tabular}{|c|c|c|c|c|c|c|c|c|}
\hline \multirow{3}{*}{$\begin{array}{c}\text { TIME } \\
\text { (h) }\end{array}$} & \multicolumn{4}{|c|}{ PD } & \multicolumn{4}{|c|}{ PAD } \\
\hline & \multicolumn{2}{|c|}{$\begin{array}{l}\text { SWELLING POWER } \\
(\%)\end{array}$} & \multicolumn{2}{|c|}{ SOLUBILITY (\%) } & \multicolumn{2}{|c|}{ SWELLING POWER } & \multicolumn{2}{|c|}{ SOLUBILITY (\%) } \\
\hline & $\stackrel{(\%)}{55^{\circ} \mathrm{C}}$ & $95{ }^{\circ} \mathrm{C}$ & $55^{\circ} \mathrm{C}$ & $95^{\circ} \mathrm{C}$ & $\stackrel{(\%)}{55^{\circ} \mathrm{C}}$ & $95^{\circ} \mathrm{C}$ & $55^{\circ} \mathrm{C}$ & $95^{\circ} \mathrm{C}$ \\
\hline 0 & $4,6 \pm 0,04^{a}$ & $41,8 \pm 0,31^{a}$ & $0,89 \pm 0,00^{a}$ & $16,0 \pm 0,11^{\mathrm{a}}$ & $2,6 \pm 0,02^{a}$ & $21,3 \pm 0,27^{a}$ & $1,9 \pm 0,64^{a}$ & $26,8 \pm 0,26^{a}$ \\
\hline 24 & $2,8 \pm 0,01^{b}$ & $29,0 \pm 0,01^{b}$ & $0,56 \pm 0,02^{b}$ & $12,0 \pm 0,17^{b}$ & $2,5 \pm 0,06^{b c}$ & $20,3 \pm 0,21^{b}$ & $1,2 \pm 0,01^{b}$ & $25,4 \pm 0,24^{b}$ \\
\hline 72 & $2,7 \pm 0,01^{c}$ & $27,5 \pm 0,54^{c}$ & $0,22 \pm 0,00^{c}$ & $11,7 \pm 0,41^{\mathrm{b}}$ & $2,4 \pm 0,02^{\text {bd }}$ & $18,2 \pm 0,22^{\mathrm{c}}$ & $1,1 \pm 0,02^{c}$ & $24,9 \pm 0,29^{\text {cd }}$ \\
\hline 96 & $2,7 \pm 0,02^{c}$ & $27,6 \pm 0,12^{\mathrm{c}}$ & $0,11 \pm 0,00^{d}$ & $11,7 \pm 0,01^{\mathrm{bc}}$ & $2,4 \pm 0,01^{\text {bd }}$ & $17,3 \pm 0,13^{d}$ & $1,1 \pm 0,01^{c}$ & $24,2 \pm 0,23^{d}$ \\
\hline 144 & $2,5 \pm 0,01^{d}$ & $25,8 \pm 0,27^{d}$ & * & $11,4 \pm 0,01^{b c}$ & $2,3 \pm 0,01^{\mathrm{e}}$ & $15,4 \pm 0,32^{\mathrm{e}}$ & $0,7 \pm 0,01^{d}$ & $24,6 \pm 0,34^{\mathrm{cd}}$ \\
\hline 192 & $2,5 \pm 0,00^{d}$ & $25,8 \pm 0,77^{d}$ & * & $11,5 \pm 0,01^{\mathrm{bc}}$ & $2,2 \pm 0,02^{f}$ & $15,7 \pm 0,12^{\mathrm{e}}$ & $0,4 \pm 0,06^{\mathrm{e}}$ & $23,7 \pm 0,28^{\text {de }}$ \\
\hline 240 & $2,4 \pm 0,02^{\mathrm{e}}$ & $23,8 \pm 0,20^{\mathrm{e}}$ & * & $11,1 \pm 0,05^{\mathrm{d}}$ & $2,2 \pm 0,03^{f}$ & $13,1 \pm 0,30^{f}$ & $0,1 \pm 0,01^{\dagger}$ & $23,5 \pm 0,13^{e}$ \\
\hline
\end{tabular}

${ }^{1}$ Equal letters in the same column do not differ significantly at the $5 \%$.

*Not detected.

\subsection{GELATINIZATION TEMPERATURE}

The results of the gelatinization analysis of the PD and PAD samples are shown in the Table 3 and Figures 4 and 5. All the annealed samples suffered increases in $T_{0}, T_{p}$ and $\Delta H$, in relation to the control sample. The gelatinization enthalpy $(\Delta \mathrm{H})$ of the PAD annealed for $240 \mathrm{~h}$ increased $9,7 \%$ in relation to the PD annealed for the same time.

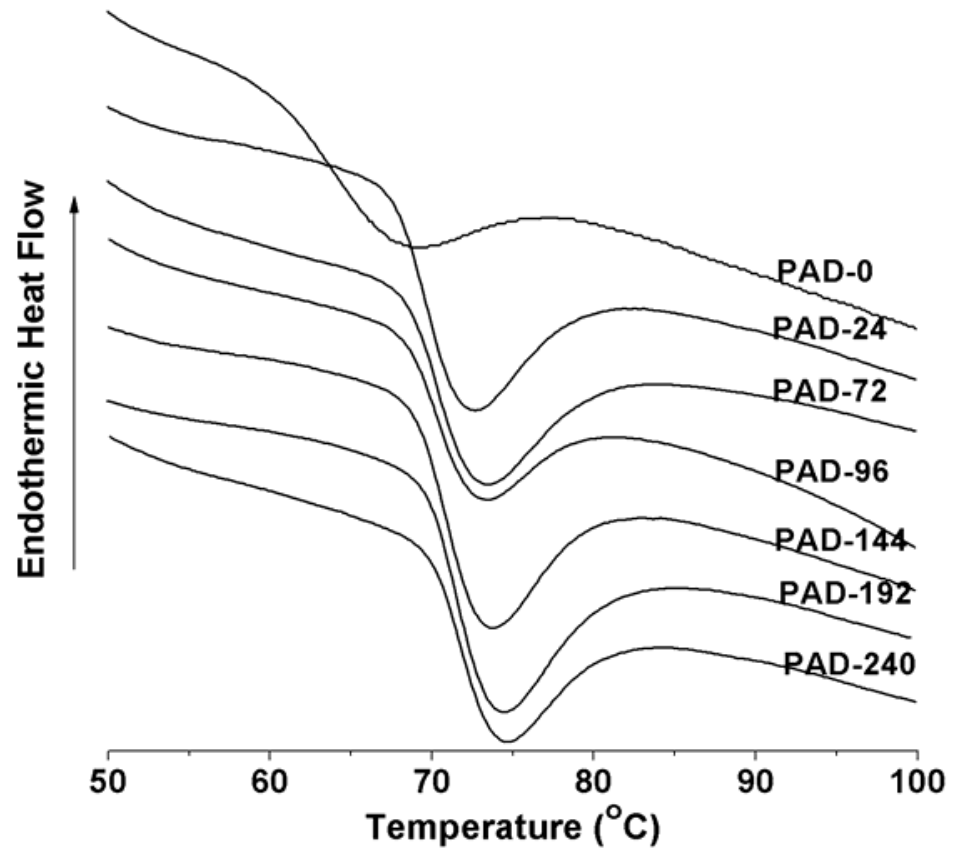

FIGURE 4 - DSC CURVE OF NATIVE AND ANNEALED PAD STARCHES 
The increase in the gelatinization temperatures and the narrowing of the gelatinization range may have been caused by an alteration in the coupling forces among the amorphous and crystalline parts, as a consequence of the reinforcement in the packing of the double helices of the amylopectin.

TABLE 3 - EFFECTS OF ANNEALING ON THE GELATINIZATION CHARACTERISTICS OF THE SAMPLES OF PD AND PAD

\begin{tabular}{ccccccccc}
\hline TIME & \multicolumn{9}{c}{$\mathrm{PD}$} \\
\cline { 2 - 8 }$(\mathrm{h})$ & $\mathrm{T}_{\mathrm{O}}\left({ }^{\circ} \mathrm{C}\right)$ & $\mathrm{T}_{\mathrm{P}}\left({ }^{\circ} \mathrm{C}\right)$ & $\Delta \mathrm{T}$ & $\Delta \mathrm{H}(\mathrm{J} / \mathrm{g})$ & $\mathrm{T}_{\mathrm{O}}\left({ }^{\circ} \mathrm{C}\right)$ & $\mathrm{T}_{\mathrm{P}}\left({ }^{\circ} \mathrm{C}\right)$ & $\Delta \mathrm{T}$ & $\Delta \mathrm{H}(\mathrm{J} / \mathrm{g})$ \\
\hline 0 & 58,6 & 67,1 & 13,3 & 5,1 & 61,7 & 69,4 & 10,2 & 3,3 \\
24 & 65,7 & 70,2 & 10,0 & 6,1 & 67,1 & 72,2 & 10,3 & 9,1 \\
72 & 66,6 & 70,9 & 11,3 & 8,2 & 68,4 & 73,2 & 11,4 & 12,4 \\
96 & 67,1 & 71,3 & 10,2 & 5,4 & 68,7 & 73,3 & 10,1 & 7,2 \\
144 & 67,2 & 71,3 & 9,7 & 7,1 & 69,1 & 74,0 & 10,1 & 7,5 \\
192 & 67,4 & 71,4 & 10,0 & 7,6 & 70,0 & 74,7 & 11,2 & 11,1 \\
240 & 67,3 & 71,5 & 10,0 & 7,6 & 70,0 & 74,7 & 10,1 & 8,4 \\
\hline
\end{tabular}

$\mathrm{Tp}=$ peak temperature; $\Delta \mathrm{T}=$ temperature range (Tc-To); $\Delta \mathrm{H}=$ enthalpy.

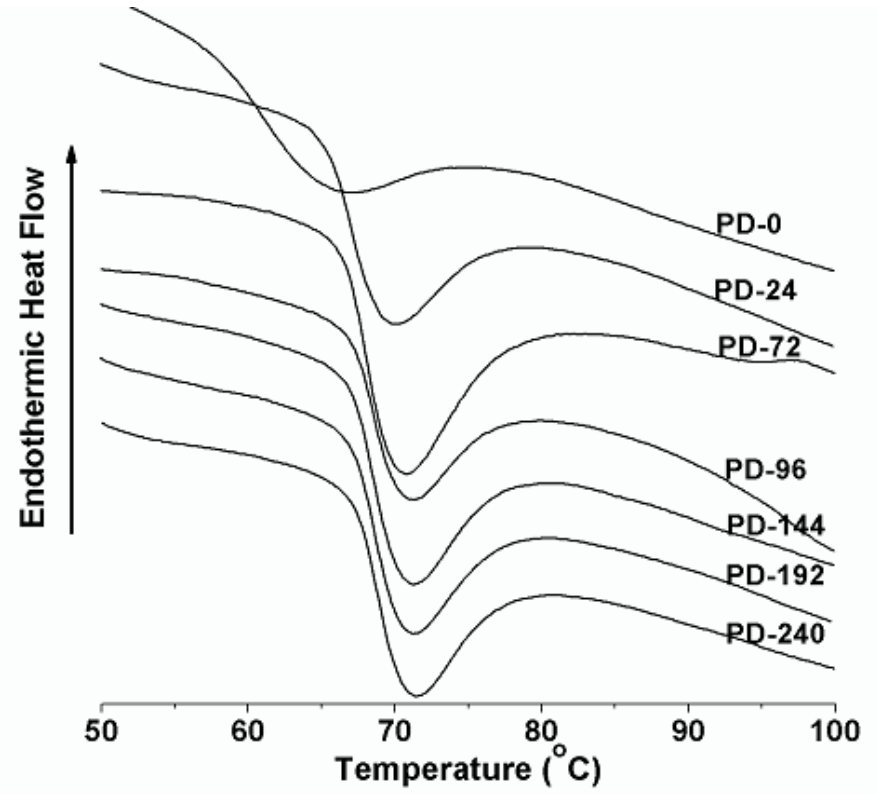

FIGURE 5 - DSC CURVE OF NATIVE AND ANNEALED PD STARCHES

The enthalpy of gelatinization of PAD-0 was much smaller than the PD-0, which was probably a consequence of the fermentation process occurred in PAD-0, which become the links weaker and that may be broken under heating. For this reason the energy used to break them was lower.

The annealing treatment induced to a reorganization of the molecules, which provoked the increase in the enthalpy and temperatures of gelatinization. With the increase of time of treatment, the molecules of PAD seemed to have suffered a more pronounced rearrangement than the ones of PD, because the latter already has a higher degree of organization between its molecules. 
The intensities in the main peaks diffraction and the relative crystallinities (RC) of the PD and PAD samples are presented in the Table 4 and Figures 6 and 7 . There were no modifications in $x$-ray patterns of annealed samples, but the main diffraction peaks $\left(14^{\circ}, 15^{\circ}, 17^{\circ}, 18^{\circ}\right.$ e $\left.23^{\circ}\right)$ showed increase on diffraction intensity, principally in PAD samples.

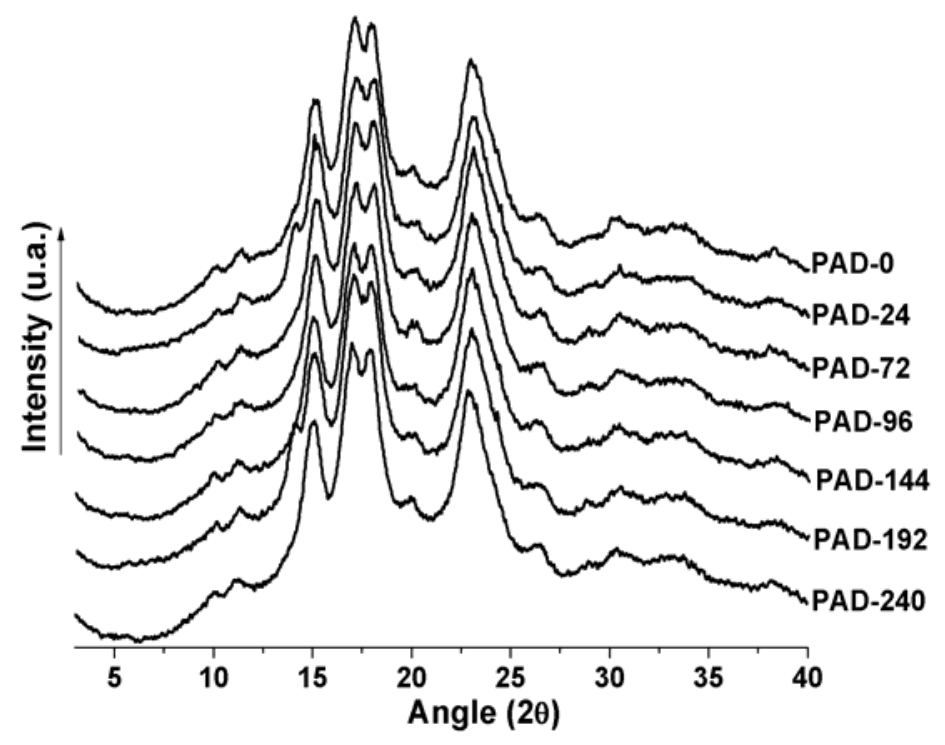

FIGURE 6 - X-RAY DIFFRACTION PATTERNS OF NATIVE AND ANNEALED PAD STARCHES

The PAD sample presented RC 3,0\% larger than the PD. The PAD annealed by $240 \mathrm{~h}$ presented intensity increased in the rings $17^{\circ}, 18^{\circ}$ and $23^{\circ}$, in relation to the control sample. The PAD sample annealed for $72 \mathrm{~h}$ presented higher intensity in almost all the rings. The increase in RC after annealing indicates that the crystalline structures acquired a more compact and organized packing.

The unfermented and fermented cassava starches (PD and PAD) untreated presented an $x$-ray pattern type $C_{A}$ and $A$, respectively. The $C_{A}$ pattern is an intermediate between $A$ and $B$ pattern, but shows majors characteristics of type $A$. The $C_{A}$ pattern shows main peaks at $14^{\circ}, 15^{\circ}, 17^{\circ}, 18^{\circ}, 20^{\circ}$ and $23^{\circ}(2 \theta)$. The A pattern shows main peaks at $15^{\circ}, 17^{\circ}, 18^{\circ}, 20^{\circ}$ and $23^{\circ}(2 \theta)$. The PAD samples presented more narrow peaks, indicating that the hydrolysis during the fermentation process attacked the amorphous areas, leaving intact the crystalline ones. The PD samples presented broader peaks, indicating larger presence of amorpho ic motarial

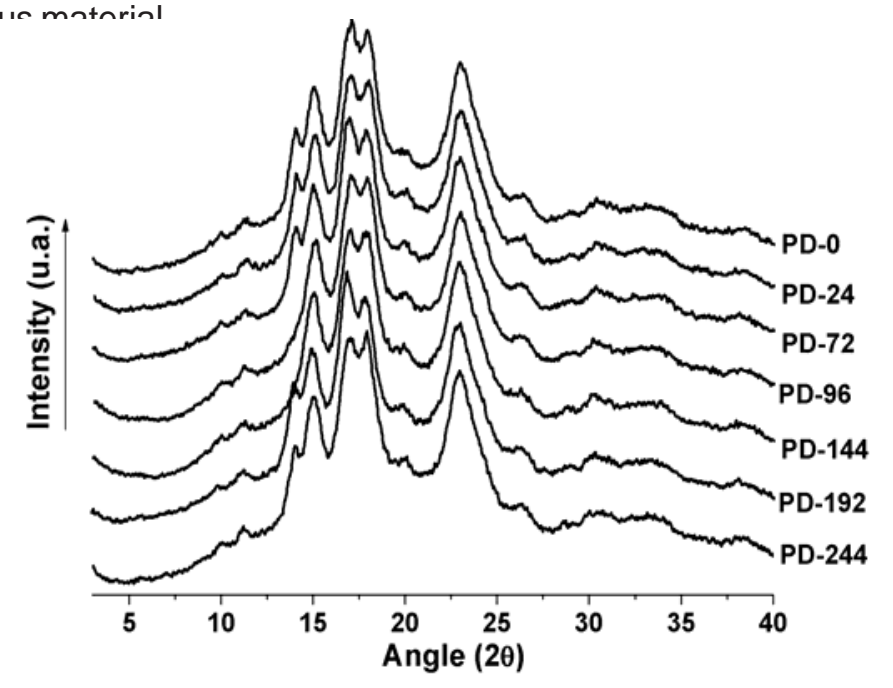

FIGURE 7 - X-RAY DIFFRACTION PATTERNS OF NATIVE AND ANNEALED PD STARCHES 


\section{TABLE 4 - EFFECTS OF ANNEALING ON THE INTENSITIES OF THE MAIN PEAK DIFFRACTION AND THE RELATIVE CRYSTALLINITIES OF THE PD AND PAD}

\begin{tabular}{|c|c|c|c|c|c|c|c|c|}
\hline \multirow{3}{*}{$\begin{array}{c}\text { TIME } \\
\text { (h) }\end{array}$} & \multicolumn{4}{|c|}{ PD } & \multicolumn{4}{|c|}{ PAD } \\
\hline & \multicolumn{3}{|c|}{${\text { INTENSITIES }(A U)^{1}}^{1}$} & \multirow{2}{*}{$\begin{array}{l}\mathrm{RC} \\
(\%)\end{array}$} & \multicolumn{3}{|c|}{ INTENSITIES $(A U)^{1}$} & \multirow{2}{*}{$\begin{array}{l}\mathrm{RC} \\
(\%)\end{array}$} \\
\hline & $17^{0}$ & $18^{\circ}$ & $23^{\circ}$ & & $17^{0}$ & $18^{\circ}$ & $23^{\circ}$ & \\
\hline 0 & 3441 & 3331 & 2988 & $17,4 \pm 0,24$ & 3417 & 3359 & 3018 & $17,9 \pm 0,10$ \\
\hline 24 & 3233 & 3130 & 2854 & $17,1 \pm 0,08$ & 3398 & 3424 & 3026 & $19,2 \pm 0,01$ \\
\hline 72 & 3334 & 3199 & 2894 & $16,5 \pm 0,15$ & 3429 & 3449 & 3241 & $19,3 \pm 0,07$ \\
\hline 96 & 3339 & 3272 & 2897 & $16,5 \pm 0,07$ & 3384 & 3362 & 3040 & $18,5 \pm 0,10$ \\
\hline 144 & 3328 & 3118 & 2773 & $16,6 \pm 0,08$ & 3348 & 3320 & 3061 & $18,5 \pm 0,17$ \\
\hline 192 & 3231 & 3250 & 2854 & $16,3 \pm 0,11$ & 3514 & 3418 & 2995 & $18,7 \pm 0,05$ \\
\hline 240 & 3253 & 3319 & 2917 & $16,9 \pm 0,05$ & 3448 & 3402 & 3032 & $18,7 \pm 0,02$ \\
\hline
\end{tabular}

${ }^{1} \mathrm{AU}=$ arbitray unity.

\section{CONCLUSION}

The annealing treatment changed the physicochemical characteristics of the cassava starches. In almost all determinations, the PAD samples seemed to be more affected by this treatment than PD ones, because the latter already has a higher organization while in PAD, the bonds are weakened by fermentation process (hydrolysis of starch bonds) and hence they are more prone to reorganization. The PAD samples presented some characteristics of a waxy starch, such as increased crystallinity and increased stability of the pastes, which from a technological point of view is very important to diversify further its use in the food industry.

\section{RESUMO}

\section{ANNEALING DOS AMIDOS DE MANDIOCA NÃO FERMENTADO (POLVILHO DOCE) E FERMENTADO (POLVILHO AZEDO)}

Os efeitos do annealing nas propriedades dos amidos de mandioca fermentado (polvilho azedo - PAD) e não fermentado (polvilho doce - PD) foram analisados. As amostras foram submetidas ao tratamento annealing por $24,72,96,144,192$ e 240 horas. O tratamento modificou as propriedades físico-químicas (entalpia e temperatura de gelatinização) e reológicas (poder de inchamento, temperatura de pasta e viscosidade máxima) de ambos os amidos. O aumento nas temperaturas de gelatinização e o estreitamento na faixa de gelatinização foram atribuídos ao fortalecimento no arranjo das duplas hélices da amilopectina. O PAD mostrou-se mais afetado pelo tratamento annealing que o PD. O polvilho azedo apresentou algumas características de amido ceroso, como aumento da cristalinidade e da estabilidade das pastas, o que sob o ponto de vista tecnológico é muito importante para diversificar ainda mais a sua utilização na indústria de alimentos.

PALAVRAS-CHAVE: AMIDO DE MANDIOCA; POLVILHO DOCE; POLVILHO AZEDO; ANNEALING.

\section{REFERENCES}

1 CEREDA, M. P. Tecnologia e qualidade do polvilho azedo. Informe Agropecuário, v. 13, p. 63-68, 1987.

2 EERLINGER, R. C.; JACOBS, H.; BLOCK, K. Effects of hydrothermal treatments on the rheological properties of potato starch. Carbohydrate Research, v. 297, p. 347-356, 1997.

3 ELIASSON, A. C.; GUDMUNDSSON, M. Starch: physicochemical and functional aspects. In ELIASSON, A. C. (Org.). Carbohydrates in foods. Orlando, FL: Academic Press, 1996. p. 184-248. 
4 FUJITA, S.; YAMAMOTO, H.; SUGIMOTO, Y.; MORITA, N.; YAMAMORI, M. Thermal and crystalline properties of waxy wheat (Triticum aestivum L) starch. Journal of Cereal Science, v. 27, p. 1-5, 1998.

5 GOMES, A. M. M.; DA SILVA, C. E. M; RICARDO, N. M. P. S; SASAKI, J. M.; GERMANI, R. Impact of annealing on the physicochemical properties of unfermented cassava starch ("Polvilho Doce"). Starch/Stärke, v. 56, p. 419-423, 2004.

6 GOUGH, B. M.; PYBUS, J. N. Effect on the gelatinization temperature of wheat starch granules of prolonged treatment with water at $50^{\circ} \mathrm{C}$. Starch/Stärke, v. 23, p. 210-212, 1971.

7 HOOVER, R.; VASANTHAN, T. J. The effect of annealing on the physicochemical properties of wheat, oat, potato and lentil starches. Journal of Food Biochemistry, v. 17, p. 303-325, 1994.

8 JACOBS, H.; DELCOUR, J. A. Hydrothermal modifications of granular starch, with retention of the granular structure: a review. Journal of Agriculture and Food Chemistry, v. 46, p. 2895-2905, 1998.

9 JACOBS, R.; EERLINGEN, R. C.; CLAUWAERT, W.; DELCOUR, J. A. Influence of annealing on the pasting properties of starches from varying botanical sources. Cereal Chemistry, v. 72, n. 5, p. 480-487, 1995.

10 KARLSSON, M. A.; ELIASSON, A. C. Effects of time/temperature treatments on potato (Solanum tuberosum) starch: a comparison of isolated starch and starch in situ. Journal of the Science of Food and Agriculture, v. 83, p. 1587-1592, 2003.

11 LARSSON, I.; ELIASSON, A. C. Annealing of starch at an intermediate water content. Starch/Stärke, v. 43, p. 227231, 1991.

12 LIM, S. -T.; CHANG, E. -H.; CHUNG, H. -J. Thermal transition characteristics of heat-moisture treated corn and potato starches. Carbohydrate Polymers, v. 46, p. 107-115, 2001.

13 MICROCAL SOFTWARE INC. Origin 6.0. Massachusetts, 1996.

14 NAKAZAWA, Y.; WANG, Y. J. Acid hydrolysis of native and annealed starches and branch- structure of their Naegeli dextrins. Carbohydrate Research, v. 338, p. 2871-2882, 2003.

15 NEWPORT SCIENTIFIC. Operation manual for series 4: instructions manual. Warriewood: Australia, 1998,123 p.

$16 \mathrm{SCHOCH}$, J. T. Swelling power and solubility of starch. In: WHISTLER, R. L.; SMITH, R. J.; BEMILLER, I. N. (Org.). Methods in carbohydrate chemistry. London: Academic Press, 1964. p. 106-108.

17 SHIMADZU CORPORATION. Operation manual for DSC-50: instruction manual. Kyoto: Japan, 1989.

18 STUTE, R. Hidrothermal modification of starches: the difference between annealing and heat-moisture treatment. Starch/Stärke, v. 44, n. 6, p. 205-214, 1992.

19 TESTER, R. F.; ANSEL, R.; SNAPE, C. E.; YUSUPH, M. Effects of storage temperatures and annealing conditions on the structures and properties of potato (Solanum tuberosum). International Journal of Biological Macromolecules, v.36, p. 1-8, 2005.

20 TESTER, R. F.; DEBON, J. J. Annealing of starch - a review. International Journal of Biological Macromolecules, v. 27 , p. $1-12,2000$.

21 VERMEYLEN, R.; GODERIS, B.; DELCOUR, J. A. An X-ray study of hydrothermally treated potato starch. Carbohydrate Polymers, v. 64, p. 364-375, 2006.

22 WANG, W. I.; POWEL, A. D.; OATES, C. G. Effects of annealing on the hydrolysis of sago starch. Carbohydrate Polymers, v. 33, p. 195-202, 1997.

\section{ACKNOWLEDGEMENTS}

CAPES and FUNCAP provided financial support for this work. 